Article

\title{
Platform and Data Co-Operatives amidst European Pandemic Citizenship
}

\author{
Igor Calzada ${ }^{1,2} \mathbb{D}$ \\ 1 Urban Transformations ESRC \& Future of Cities Programmes, COMPAS, University of Oxford, \\ 58 Banbury Road, Oxford OX2 6QS, UK; igor.calzada@compas.ox.ac.uk; Tel.: +44-7887-661925 \\ 2 Digital Economy Unit \& Centre for Advanced Studies (CAS), DG Joint Research Centre (JRC), \\ European Commission, Via Fermi 2749, 21027 Ispra, Italy
}

Received: 24 August 2020; Accepted: 7 October 2020; Published: 9 October 2020

check for updates

\begin{abstract}
Many European pandemic citizens will likely be unemployed during the COVID-19 crisis. This article explores whether it is possible to alter existing data governance extractivist models to incentivize the emergence of platform and data co-operatives to protect European pandemic citizens' labor and digital rights. As such, this article aims to decipher the rationale behind the proliferation of platform and data co-operatives by responding to how new forms of co-operatives using digital technologies can provide feasible socio-economic alternatives to improve post-COVID-19 working conditions for vulnerable or already empowered pandemic citizens. This article is structured as follows. First, the European "pandemic citizenship" term is described. Second, the rationale of this article is consequently presented. Third, the research question, two hypotheses, and the action research triangulation are described. The deployment of the triangulation methodology based on action research, mixed methods and social innovation reveals the main findings through (i) Delphi study results, (ii) a taxonomy for platform and data co-operative cases, and ultimately, (iii) fieldwork research conducted in Glasgow, Barcelona and Tallinn. This article concludes that co-operatives (platform-based or data-driven), stemming from the potential resilient response of European pandemic citizens, may currently portray a feasible alternative to data governance extractivist models.
\end{abstract}

Keywords: pandemic citizenship; co-operatives; COVID-19; GDPR; platform co-operatives; data co-operatives; social innovation; action research; digital rights; foundational economy

\section{Introduction: Amidst European Pandemic Citizenship}

In Europe, many citizens have been or will likely be unemployed during the course of COVID-19 [1-9]. The coronavirus does not discriminate, yet its economic and social impact have been unevenly distributed, even across and within state borders, through a new pandemic citizenship regime that reveals health, socio-economic, cognitive, and even digital vulnerabilities [10]. By contrast, the COVID-19 pandemic has also shown that the platform economy can offer opportunities-while also exposing citizens to pervasive multifaceted vulnerabilities and precarious labor conditions- to continue working and earning even during times of crisis [11,12]. How, though, can job quality be ensured for all platform workers, while further democratic socio-economic platformized alternatives are also being proliferated to revert to the algorithmic and "data-opolitic" (data oligopolies) extractivist business-as-usual hegemonic paradigm [13]? And how might the transnational quality of these platforms challenge the way co-operatives historically have been understood, rooted, and localized in Europe [14-26]?

Over the last decades, globalization has led to a new class of global citizenship for workers [27]. While access to this global citizenship remains uneven, many have enjoyed unlimited freedom to move, work, and travel. However, COVID-19 has drastically slowed down this global citizenship 
regime, and introduced a new level of ubiquitous vulnerabilities in global affairs by inciting a new pandemic citizenship regime under which citizens-regardless of their locations-share fear, uncertainty, and risks [23]. Furthermore, COVID-19 is pervasively related to data and artificial intelligence (AI) governance issues, which expose citizens' vulnerabilities under a potential surveillance state [28] and capitalism [29]. The responses to this pandemic emergency have varied extremely by location, even within the same state. Among the resilience strategies adopted by European governments, collective intelligence stemming from a proactive citizenship response has been highly considered by several European city-regions to avoid dystopian measures that could exacerbate existing social inequalities and techno-political vulnerabilities among European pandemic citizens [30-33]. One collective intelligence response emerging in Europe is the creation of digital co-operatives [34-36], also known as platform co-operatives [8,37-39] and data co-operatives [40-45].

Historically, co-operatives have been created when people work together-now with the help of technology - to respond with collective resilience to complex crises, and to mobilize a wider range of information, ideas, labor, and insights to address structural social transformations through disruptive economic innovations [24,46]. The co-operative movement began in the UK and France in the 19th century. Remarkably, though, several unique regionally rooted experiences with strong communitarian identities have flourished in Europe since then, such as the Mondragon case in the Basque Country (Spain) in the 1950s [25,47-50] and the Emilia Romagna case (Italy) in the late 1970s [51-55].

At present, alongside the creation of 'digital' co-operatives [56], several resilience strategies for tackling the COVID-19 stemming from social innovation [26] are worth considering in Europe from a perspective of advocacy for digital transformations, as follows: (i) predicting and modeling AI systems, (ii) citizens' science projects with real-time data, (iii) social media mining, (iv) open-source Do-It-Yourself (DIY), and (iv) coronavirus detection tests and contact tracing/tracking apps [57].

Against this backdrop, European citizens working in tourism, the arts, retail, and education, and all informal workers, are the hardest hit by the COVID-19 pandemic [19]. Further, low-income marginalized working-class citizens and immigrants are more adversely affected than the average of the standard population [58]. Income inequality is growing, confidence in governments is eroding, and increasingly more people are embracing populism [59]. Workers may lose power and a sense of agency over their lives, and consequently their own data $[60,61]$. To this end, how can working citizens organize, regain control of their data, and participate in building socio-economic alternatives to alter the existing data governance extractivism to protect pandemic European citizens' digital rights [62]? How does European citizenship (reacting to this threat and, therefore, self-organizing) challenge data extractivism [63] and surveillance capitalism [29]? Is there any alternative response to big tech AI-driven "data-opolies" [64-67]? What will be next? Amazon workers walking out may be just the beginning $[68,69]$. The Great Depression gave rise to the original New Deal. Is there any Tech New Deal out there [56]? In this direction, new possibilities for how Europe could improve beyond considering the citizen a simple resource have already been posed in the widely spread manifesto '\#DemocratizingWork: Democratize, Decommodify, Remediate' [70], signed by relevant academics worldwide.

As such, this article aims to decipher the rationale behind the platform and data co-operatives by providing evidence-based research and policy analysis, and by responding to how new forms of co-operatives using digital technologies can provide a framework to rethink, renew, and offer alternatives to the way policies on digital transformations and AI can help enhance pandemic citizens' well-being and thus improve the post-COVID-19 working conditions of vulnerable and already empowered pandemic citizens [71]. This article thus reflects upon how democratic and participatory platforms can offer new non-capitalist labor environments in a post-COVID-19 world. Consequently, European "pandemic citizenship" in this article is defined as follows: The post-COVID-19 era, on the one hand, has dramatically slowed down several mundane routines for citizens, such as mobility patterns, while, on the other hand, new demanding professional pressures, emotional fears, life uncertainties, algorithmic exposure, data privacy concerns, health-related direct risks, 
and socio-economic vulnerabilities (depending eminently on the material and living conditions shared by a wide range of citizens, regardless of their specific localization in Europe) have exponentially emerged.

The article is structured as follows. The next section presents the rationale behind this article by linking between the term European "pandemic citizenship" and the platform/data co-operatives phenomenon. The third section presents the research question, two hypotheses, and the action research triangulation methodology. The deployment of the triangulation methodology based on action research, mixed methods and social innovation reveals the main findings of this study through (i) Delphi study results, (ii) a taxonomy encompassing four typologies for platform and data co-operative cases, and ultimately, (iii) the comparative fieldwork research conducted in the city-regions of Glasgow, Barcelona and Tallinn. The last section concludes by not only responding to the research question and commenting on both hypotheses, but also offering a future research pathway for platform and data co-operatives.

\section{Rationale: European Pandemic Citizenship and Platform/Data Co-operatives at Stake}

There is a growing consensus in Europe that it is urgent for governments to start filling the same role in the information society that they have traditionally taken in the industrial society: not only fixing market failure but also regulating the digital power relations and supervising their actual economic interplay among stakeholders. This means not just demanding fair tax payments by the big tech companies and imposing fines when they violate the General Data Protection Regulation (GDPR) by extracting personal data, or when they abuse their market power. There are more fundamental issues at stake that call for government attention beyond intervention. The COVID-19 crisis has clearly shown that citizens are highly dependent on data and the economic value it creates. The COVID-19 crisis has led thus to a necessary revaluation in society of the roles of both governments and citizens, in which digitization and datafication are at the core of economic and socially innovative alternatives [26]. These alternatives are platform and data co-operatives [72].

Therefore, post-COVID-19, as the concentration of big tech companies is skyrocketing, platform and data co-operatives should not stop at an analysis of surveillance capitalism; they might equip citizens to succeed and build alternatives as cooperative platform entrepreneurs or activists in the fast-growing gig economy [73-76]. They might give members of the co-operative the opportunity to analyze and get involved with a generation of citizens experimenting with innovative power-building strategies rooted in the cooperative ownership of digital platforms and data storages [77]. Could we imagine Uber owned by the drivers or Twitter owned by its users [78]? Ultimately, advocates of platform and data co-operatives suggest that a shift from a sharing economy to a genuinely participatory and democratically owned economy might be possible $[7,8,37]$.

Nonetheless, to provide a neutral and objective scientific standpoint, this article attempts to strike a balance among positions on co-operatives, including a less convinced and more critical counterargument stemming from past and contemporary stances on co-operatives. Rosa Luxemburg argued that workers forming a co-operative in the field of production were faced with the contradictory necessity of governing themselves with the utmost absolutism [79]. According to her, these workers were obliged to themselves assume the role of capitalist entrepreneur-a contradiction that accounts for the usual failure of production co-operatives, which either become pure capitalist enterprises or, if the workers' interests continue to predominate, end by dissolving. In a similar vein, the updated criticisms by Sandoval [80] and Siapera and Papadopoulou [81] draw out the problematic implications of an uncritical embrace of entrepreneurialism, and highlight the need to defend a politics of social solidarity, equality, and public goods-the only way to reshuffle the entire capitalistic system [82]. These interpretations eminently claim an existing dichotomy between democracy and the market, avoiding market-orientated operations (referring to platform co-operatives) and embracing social solidarity and a global co-operative movement, rather than co-operative entrepreneurs, as the only way to subvert the capitalist enterprise society [24]. Furthermore, is it possible that data extractivism as 
a form of capitalist exploitation in the globalized data economy could be negated through participatory co-operative platforms? Or, by contrast, are such platforms inherently (and contradictorily) part of the capitalist system, as the fierce and pure Marxist or Anarchist critics suggested [59,83]? Although the debate is still open, a new generation of social entrepreneurs at the Mondragon Co-operatives might challenge these assumptions as being overly critical, too ideological, too highly theoretical, and far removed from ongoing global social challenges [24].

Overall, co-operatives could be considered a movement of citizens in Europe that accounts for 130,000 enterprises in Europe in basically all economic sectors, with 127 million members, more than 4 million employees, and a nearly EUR 990 billion annual turnover [84]. However, the understanding, practices, and perceptions of co-operatives vary significantly from state to state-particularly now in the post-COVID-19 era-and show a substantial path dependency on contextual factors derived from history and from current digital and socio-political transformations. As a generalization of historical trends, two distinct citizenship regimes have framed and shaped the perception of co-operatives. First, in the Western European co-operative regime, there is sometimes a concern that many small and local platform and data co-operatives seem to be approaching the co-operative model mainly for ideological and value reasons, and clearly underestimate the economic dimension of a sustainable business model in a competitive global context. This approach leads to a high risk of failure beyond the purely altruistic, volunteer, civilian, and grassroots-driven initiatives, which are far removed from formal professional entrepreneurial institutions. The second regime appears in the Eastern European co-operative tradition. In essence, the communist legacy left a generalized distrust of the population in terms of the co-operative concept. This distrust is still linked to the memory of past communist collectives, and has been clearly replaced by an individualistic general preference for private ownership of assets over sharing or direct exchange with peer citizens.

The notion of co-operatives in the digital era-eminently as a transnational phenomenon-cannot be dissociated from the emerging pandemic citizenship regime in Europe across state borders [10]. Such a pandemic citizenship regime is actually the seed for creating co-operative forms in the digital economy and society that aim to protect citizens' digital rights, such as platform and data co-operatives.

As such, this article analyzes the approach to citizenship in Europe through the lens of the COVID-19 [33]. Citizenship encompasses concepts of not only identification and belonging, but also power, control, and techno-politics [85-87]. Long before COVID-19 swept the globe, insecurity and social vulnerabilities were already ubiquitous. Countless citizens have faced housing, health, and food insecurity. Prior to the advent of social distancing, citizens hid behind doors, locks, gates, and border walls, afraid of both public space and one another. Meanwhile, online, citizens have long fretted over information security, devising passwords to access passwords, fearful they might be hacked or exposed. Citizens are insecure in their jobs, homes, and relationships, and on social media. Citizens feel insecure about themselves as well. Co-operatives may thus mean building a more secure economy and society for everyone. It is a challenge Europe cannot afford to ignore [23].

Amidst post-COVID-19 insecurity, online videoconferencing shows a clear example of how extractivist (capitalist) platforms may be gradually fostering the emergence of further citizen-owned platforms, driven by co-operative principles [21]. While Zoom's privacy policy outlines some rather concerning data collection practices [88], a new co-operative open-source version is emerging as a prototype: The Online Meeting Co-operative [89].

However, co-operatives' far-reaching aspirations are based on the idea that digital revolutionaries should reshape everything but the central institution of modern life: the market. As such, while big data and AI do not naturally favor non-market activities, they do make it easier to imagine a post-neoliberal world where production is automated, and technology underpins universal healthcare and education for all in the post-COVID-19 era-a world where abundance is shared by peers, not appropriated [83]. Today's debate on the right technological response to COVID-19 revolves around, on the one hand, the trade-offs between civilian liberties, data privacy, and public health [90], and on the other, the need to promote innovation by start-ups. This is because we have let digital platforms and telecom operators 
treat our entire digital universe as their fiefdom. They run it with just one goal in mind: keep the micro-targeting going and the micro-payments flowing. As a result, little thought has gone into building digital technologies that produce macro-level anonymous insights into the collective behavior of non-consumers. The digital platforms, as they are hegemonically known today, are the sites of individualized consumption, not of mutual assistance and solidarity [80,81]. Thus, could digital platform innovation in Europe be led by an asymmetric network of co-operative SMEs [15,18]?

Over the last few decades, the EU has increasingly operated online; its scattered geography has allowed political decisions and national laws to transform physical space into virtual territory. Digital economies are now integrated, citizens are mobile, and the cyber- or techno-political domain is merging with physical reality or the city-regional domain [32,91]. However, this virtual and analogic merger does not occur automatically, and has little respect for fixed territorial borders. As such, digital pandemic citizens today are increasingly (though unwittingly) connected through AI and machine learning devices that remain unevenly and pervasively distributed, fueling a liquid sense of global and algorithmic cosmopolitan citizenship [10,27,92-94].

Contemporary geotechnological, systems based on algorithmic citizenship through decentralized blockchain ledgers, are being implemented by the small state of Estonia-formerly the Eastern Estonian Soviet Socialist Republic - particularly through its entrepreneurial city-regional hub, Tallinn. Blockchain ledgers are decentralized information architectures, increasingly used as a consensus of replicated, shared, and synchronized digital data geographically spread across multiple sites, states, regions, cities, or institutions. These systems might offer the public sector leadership models for rethinking citizenship and potentially experimenting with platform and data co-operatives in other Western European city-regions [92,95].

In addition to Estonia's example of algorithmic citizenship, more broadly, the giant technological flagship firms of surveillance technology capitalism (such as Google and Facebook) have already assumed many functions previously associated with the European nation-state, from cartography to the surveillance of citizens, which has de-territorialized liquid citizenship [92-94]. While liquid citizens remain highly distributed in Europe, the data they produce-and particularly its ownership-are concentrated in the hands of a few companies. After the GDPR was passed, Barcelona and Glasgow became part of the Cities Coalition for Digital Rights (CCDR), which encompasses roughly 50 cities worldwide and mandates the ethical use of data to protect (smart) citizens from the risks inherent in new, data-intensive technologies.

Since March 2020, the side-effects of coronavirus have mocked immigration controls, biometrics, digital surveillance, and every kind of data analytics, and they have struck hardest-thus far-in the richest, most powerful states of the world [96]. Consequently, the significance of European algorithmic and liquid citizenship might be rapidly adjusting to pandemic citizenship, with consequences for citizens depending on which state they call home and on their living conditions. What might be called a shared pandemic citizenship_through which citizens in Europe share exactly the same fears-seems to be here to stay. This trend has different levels of techno-political implications, as it intersects with another global trend-algorithms increasingly shaping everyday life.

Arguably, the current pandemic crisis and democracy are pervasively related to data governance issues, exposing citizens' vulnerability in a potential surveillance state [28,97-103]. Should European governments protect citizens from being infected even if doing so might mean establishing a new digital non-privacy norm? Will this pandemic crisis become an algorithmic crisis, with serious side-effects for governments in Europe? Could these rapidly changing times for European pandemic citizenship be seen as an opportunity to foster digital co-operatives in Europe in pursuit of a Tech New Deal, to allow citizens and communities to own and govern their own data and platforms [56]? 


\section{Research Design and Methodology: The Research Question, Two Interrelated Hypotheses, and Action Research Triangulation}

Post-GDPR/COVID-19 Europe may require reinterpreting the way data is already affecting the nature of citizens' work, and the overall way the digital economy might function more democratically and in a way more locally rooted in cities and regions [104]. Thus, this article's analysis will focus on a citizen-driven resilient post-COVID-19 response. Consequently, the research question in this article is whether it is possible to alter existing data governance extractivism to incentivize the emergence of platform and data co-operatives, to further democratize and thus protect pandemic European citizens' labor and digital rights [105].

The interrelated hypotheses of this article regarding platform and data co-operatives, respectively, are as follows:

(i) It seems that COVID-19 has invigorated interest in co-operatives [84]. Thus, an increasing-yet marginal-tweak from the centralized and extractive platform-knows-best capitalist model towards the experiment-driven "platform co-operatives" is occurring, though this phenomenon is rather embryonic and still too weak to be consolidated due to scaling-up issues. A platform co-operative is a co-operatively owned, democratically governed business model that establishes a computing platform and uses a website and/or mobile app to facilitate the sale of goods and the delivery of services. For example, Fairbnb, a vacation rental platform, gives $50 \%$ of its revenue to local community projects; Denver's Green Taxi Cooperative is owned by its workers; and Resonate, a streaming music service, shares profits with various stakeholders.

(ii) An associated policy challenge is how to consolidate a pan-European post-GDPR AI through "data co-operatives" now that the Gaia-X project has been launched [106-109]. This policy framework enables the creation of open data and personal data stores for mutual benefit, possibly slowing the unbridled extraction of personal data by big tech private "data-opolies". City-regional authorities could establish data co-operatives to empower citizens to gain more control over their data, and allow them more of a say in the services built on and informed by these data $[110,111]$. Such practices may help to rebalance the relationship between those who create data (citizens) and those who seek to exploit those data, while creating an environment for fair and democratic exchange [112]. Data co-operatives that have fiduciary obligations to members demonstrate a promising direction for the democratic empowerment of citizens through their personal data. Without data co-operatives and related data policy ecosystems, the EU might lose its opportunity to establish a pan-European post-GDPR AI strategy $[99,113,114]$. As Aho and Duffield recently argued (p. 208), "Whilst China proceeds with constructive confidence, Europe lags behind, searching for a way to function in the global information civilization that is compatible with established Western political and social values" [67,99,115].

As such, both 'platform co-operatives' - which address alternative communitarian business/social models - and 'data co-operatives' - which aim to customize protected data stores for their members while generating a non-profit social value from doing so-share the same underlying goals: collective ownership, decentralized self-governance, transparency, and the offering of an alternative to platform capitalism [72,83,116-119].

In order to respond to the research question and contextualize both hypotheses, this article adopts an action research methodological approach [120], using mixed methods from the perspective of social innovation $[24,26,50,121]$, by using a triangulation technique [122] that encompasses:

(i) the Delphi method (Table 1);

(ii) the identification of cases (Tables 2-4);

(iii) fieldwork in three European city-region case studies (Tallinn, Barcelona, and Glasgow) [123] (Table 5). 
Table 1. Delphi Method: P2P/Commons, Platform Co-operatives, and Data Co-operatives.

\begin{tabular}{|c|c|c|c|}
\hline \multicolumn{4}{|c|}{ Delphi Method } \\
\hline Paradigm & P2P/Commons & Platform Co-Operatives & Data Co-Operatives \\
\hline Expert & Michel Bauwens & $\begin{array}{c}\text { Trebor Scholz } \\
\text { Nathan Schneider }\end{array}$ & $\begin{array}{l}\text { Thomas Hardjono } \\
\text { Alex Pentland }\end{array}$ \\
\hline Co-operative notion & $\begin{array}{l}\text { Co-operatives, just like other businesses, } \\
\text { rely on a proprietary logic and, while } \\
\text { internally democratic, still engage in } \\
\text { capitalist market competition through two } \\
\text { main drawbacks: (i) worker capitalism [79] } \\
\text { and (ii) managerialism. }\end{array}$ & $\begin{array}{l}\text { Platform co-operatives are transitions } \\
\text { to regain some control by digital } \\
\text { citizenship in the } \\
\text { post-COVID-19 scenario. } \\
\text { They aim to create social change } \\
\text { through ethical and } \\
\text { cooperative businesses. }\end{array}$ & $\begin{array}{l}\text { Data co-operatives are member-owned } \\
\text { data management storages (e.g., credit } \\
\text { unions) with fiduciary obligations to } \\
\text { members, where all data usage is for } \\
\text { the benefit of members and done only } \\
\text { with their consent; it is driven } \\
\text { by privacy-preservation. } \\
\text { Utimately, it offers insights to negotiate } \\
\text { better deals for members. }\end{array}$ \\
\hline Analysis & $\begin{array}{l}\text { - He suggests an open co-operativism as a } \\
\text { possible synthesis between common-based } \\
\text { models and co-operatives. } \\
\text { Open co-operatives could use } \\
\text { common-based reciprocity licenses that } \\
\text { continue to offer outputs free of charge as a } \\
\text { common for non-commercial uses but } \\
\text { demand a license fee for any } \\
\text { commercial usages. } \\
\text { This proposal links the commons to an } \\
\text { entrepreneurial coalition of ethical market } \\
\text { entities (co-operatives and other models) } \\
\text { and keeps surplus value entirely within the } \\
\text { sphere of commoners/cooperators/citizens, } \\
\text { instead of leaking out to multinationals. }\end{array}$ & $\begin{array}{l}\text { - The mission of platform co-operatives } \\
\text { is to diversify the digital economy as } \\
\text { Polanyi suggested with the great } \\
\text { transformation, by regulating and } \\
\text { providing incentives. } \\
\text { The idea does not destroy platform } \\
\text { capitalism but rather suggests } \\
\text { introducing tech-taxing, like in France, } \\
\text { while creating a solidarity economy. } \\
\text { The most difficult aspect about setting } \\
\text { up platform co-operatives is } \\
\text { self-organizing their activity and } \\
\text { establishing the organizational model. } \\
\text { Ownership and governance matter; the } \\
\text { largest issue is not technical. }\end{array}$ & $\begin{array}{l}\text { Data co-operatives focus on data } \\
\text { interactions among citizens and not } \\
\text { essentially in the core social value } \\
\text { behind them. } \\
\text { Data co-operatives could be seen as a } \\
\text { variation or a typology of platform } \\
\text { co-operatives (shown in the } \\
\text { next subsection) }\end{array}$ \\
\hline Economic paradigm & - Ethical economy & - Entrepreneurial economy & - Data-driven economy \\
\hline Good practices & $\begin{array}{ll}- & \text { Enspiral (New Zealand) } \\
\text { - } & \text { Fora do Eixo (Brazil) } \\
\text { - } & \text { Ethos Foundation (Switzerland) } \\
\text { - } & \text { Coop des Communs (France) }\end{array}$ & $\begin{array}{ll}\text { - } & \text { Fairmonduk (UK) } \\
\text { - } & \text { Upandgo (USA) } \\
\text { - } & \text { Eva (France) }\end{array}$ & $\begin{array}{ll}\text { - } & \text { MyData (Finland) } \\
\text { - } & \text { Salus (Catalonia/Spain) } \\
\text { Cozy (France) }\end{array}$ \\
\hline
\end{tabular}


Table 2. Definitions: Platform Co-operatives and Data Co-operatives.

\section{Platform Co-Operatives}

A platform cooperative, or platform co-op, is a cooperatively owned, democratically governed business that establishes a computing platform, and uses a website, mobile app or a protocol to facilitate the sale of goods and services. Platform cooperatives are an alternative to venture capital-funded platforms insofar as they are owned and governed by those who depend on them most-workers, users, and other relevant stakeholders.
Data Co-Operatives

Cooperative structures could enable the creation of open data and personal data stores for mutual benefit; they could rebalance what many perceive as an asymmetric relationship between data subjects (people with personal data) and data users (people who use data to develop services and products.

Members of a community voluntarily pool their data to create a commons pool for mutual benefits.

This common pool of data acts as a commons resource of collective ownership upon a framework which is collectively discussed and agreed upon.

Table 3. Taxonomy for Platform Co-operatives and Data Co-operatives.

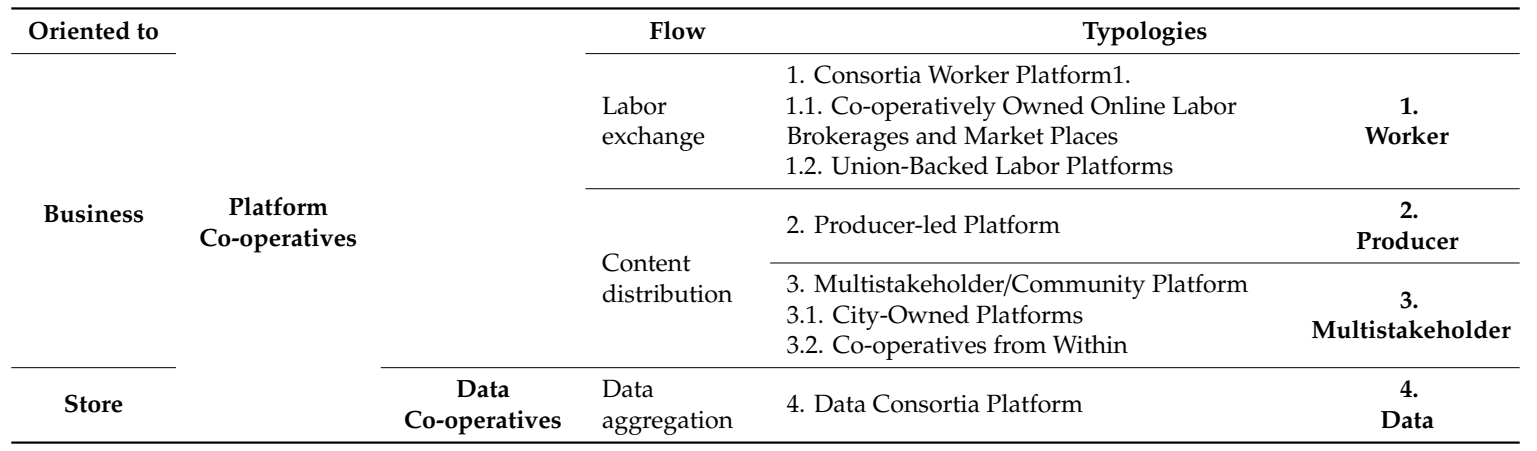

Insofar as this article aims to decipher and further investigate platform and data co-operatives amidst the European pandemic citizenship regime, the methodology was conducted as follows:

(i) The Delphi method involved approaching key experts on platform and data co-operatives to deconstruct these concepts and the post-COVID-19 context (Table 1);

(ii) Later, after platform and data co-operatives are defined (Table 2), a taxonomy of four typologies is suggested (Table 3) through the identification and location of 156 cases within the four typologies (Table 4);

(iii) Lastly, given the importance of territorial conditions for the emergence of co-operatives, the methodology includes a fieldwork research analysis conducted in Tallinn (driven by the public sector), in Glasgow (driven by the private sector), and in Barcelona (driven by civil society) (Table 5).

In summary, the triangulation technique shows complementary evidence about co-operative formation amidst the novel concept of European pandemic citizenship from three different angles. It is essential to highlight that this triangulation technique was primarily driven by a mixed method approach. 
Table 4. Case Identification by Typology.

\begin{tabular}{|c|c|c|c|c|c|}
\hline \multicolumn{6}{|c|}{ Platform Coops } \\
\hline & \multirow[b]{2}{*}{$\begin{array}{l}\text { Worker } \\
(29 ; 19 \%)\end{array}$} & \multirow[b]{2}{*}{$\begin{array}{l}\text { Producer } \\
(38 ; 24 \%)\end{array}$} & \multirow[b]{2}{*}{$\begin{array}{l}\text { Multistakeholder } \\
\quad(50 ; 32 \%)\end{array}$} & \multicolumn{2}{|r|}{ Data Coops } \\
\hline & & & & \multicolumn{2}{|r|}{$\begin{array}{c}\text { Data } \\
(39 ; 25 \%)\end{array}$} \\
\hline & $\begin{array}{c}\text { Co-operativizing } \\
\text { Work }\end{array}$ & $\begin{array}{l}\text { Co-operativizing } \\
\text { Exchange }\end{array}$ & $\begin{array}{c}\text { Co-operativizing } \\
\text { Community Services }\end{array}$ & & $\begin{array}{l}\text { Co-operativizing } \\
\text { Data }\end{array}$ \\
\hline \multicolumn{2}{|r|}{ Mobility } & $\begin{array}{l}\text { Culture, agriculture, food, software, } \\
\text { websites, hosting, start-up support, } \\
\text { videoconferencing }\end{array}$ & $\begin{array}{l}\text { Healthcare, delivery riders, media, } \\
\text { rental, housing, land }\end{array}$ & \multicolumn{2}{|r|}{ Health, finance, security } \\
\hline 1. & www.greentaxico-op.com & www.Resonate.is & www.saltspacecoop.co.uk/ & 1. & www.culedger.com \\
\hline 2. & www.Fairmondo.de & www.stocksy.com & www.formandfunction.coop/ & 2. & www.MiData.coop \\
\hline 3. & www.Loconomics.com & www.foradoeixo.org.br/ & www.graphics.coop/ & 3. & www.Salus.coop \\
\hline 4. & www.upandgo.coop & 4. www.smart-ib.coop/ & www.taskrabbit.com/ & 4. & www.cozy.io \\
\hline 5. & www.start.coop/ & 5. www.agrilyst.com & www.fairbnb.coop/ & 5. & www.mydex.org \\
\hline 6. & www.coopcycle.org/en/ & 6. www.ampled.com & www.equalcare.coop/ & 6. & www.aqdatacommons.org \\
\hline 7. & www.eva.coop/ & 7. www.ampliativeart.org & www.mensakas.com/ & 7. & www.Openhumans.org \\
\hline 8. & www.enspiral.com/ & 8. www.cleanenergycu.org & www.savvy.coop/ & 8. & www.decodeproject.eu \\
\hline 9. & www.reservation.alphataxis. & 9. www.en.goteo.org & www.thenews.coop/global/ & 9. & www.decidim.org \\
\hline & $\mathrm{fr} /$ & 10. www.ccor.org & 10. www.banyanproject.coop/ & 10. & www.meta.decidim.org \\
\hline 10. & www.co-optaxi.com/ & 11. www.cosmos.coop & 11. www.libretaxi.org/ & 11. & www.mydex.org \\
\hline 11. & www.aarhusmakers.com/ & 12. www.darkpeak.org & 12. www.ethoscharity.co.uk/ & 12. & www.opendatamanchester. \\
\hline 12. & www.applicolis.com & 13. www.docservizi.it & 13. www.coopdescommuns.org/ & & org.uk \\
\hline 13. & www.casa-comuna.coop & 14. www.dorg.tech & en/the-coop/ & 13. & www.thegooddata.org \\
\hline 14. & www.codesolid.com & 15. www.driversseat.co & 14. www.snowdrift.coop/ & 14. & www.healthbank.coop \\
\hline 15. & http://www.nesta.org.uk/ & 16. www.drutopia.org & 15. www.ampliativeart.org/ & 15. & www.ubiquitouscommons. \\
\hline & sharelab-fund-meet-grantees/ & 17. www.eten.com & 16. www.fair.coop/ & & org \\
\hline & driver-co-op & 18. www.guerrillatranslation.org & 17. www.incubator.coop & 16. & www.datacommons.coop \\
\hline 16. & www.eyemole.io & 19. www.hcoop.net & 18. www.affinity.works & 17. & www.nordicdei.org/ \\
\hline 17. & www.crowdfunder.co.uk/ & 20. www.interchanges.io & 19. www.anyshare.coop & 18. & www.givememydata.com \\
\hline & faircab & 21. www.joinus2eat.be & 20. www.bhive.coop & 19. & www.waze.com \\
\hline 18. & www.gildedsplinters.coop & 22. www.kostaki.id & 21. www.brave.coop & 20. & www.citydataexchange.com \\
\hline 19. & www.indycube.community & 23. www.marketers.coop & 22. www.coopsource.org & 21. & www.airbus.com/aircraft/ \\
\hline 20. & www.lowimpact.org & 24. www.mavfirst.coop & 23. www.collective.tools & & support-services/skywise. \\
\hline 21. & www.means.tv & 25. WwW.membersmedia.net & 24. Www.cooby.io & & html \\
\hline 22. & www.themobilityfactory.eu & 26. www.org.meet.coop & 25. www.networks.coop & 22. & www.agproexchange.com \\
\hline 23. & www.modo.coop & $\begin{array}{l}\text { 20. WwW.org.meet.coop } \\
\text { 27. www.openfoodnetwork.org/ }\end{array}$ & 26. www.pittsburgh.covivi.us & 23. & www.bankofthecommons. \\
\hline 24. & www.noncorporate.org & ofn-local/open-food-network- & www.demcra.com & & coop \\
\hline 25. & www.ridygo.fr & scandinavia/ & www.doma.city & 24. & www.cupay.coop \\
\hline 26. & www.staffing.coop & 28. www.about. & 29. Www.encode.org & 25. & www.datavest.org/ \\
\hline 27. & www.taxiapp.uk.com & openfoodnetwork.org.uk & Wrw francebarter coon & 26. & www.divvydao.org \\
\hline 28. & www.wechange.eco & 29. www.originclub.org & www.freedomcoop.eu & 27. & www.market.fair/coop \\
\hline 29. & www.wordjammers.com & 30. www.partago.be & www gebiedonline.nl & 28. & www.find.coop \\
\hline & & 31. www.thephone.coop & www.highplainsfood.org & 29. & www.gisc.coop \\
\hline & & 32. www.smart-eu.org & 34. www.kabelan.id & 30. & www.ledgerback.coop \\
\hline & & 33. www.social.coop & 34. WWW.Kadelantlu & 31. & www.mainst.market \\
\hline & & 34. www.sofcoop.org & re-imagining-childcare- & 32. & www.moeda.in \\
\hline & & 35. www.vngrd.online & introducing-kidoop & 33. & www.opencredit.network \\
\hline & & 36. www.webarchitects.coop & 36. www.knowledgeatlas.com & 34. & www.patientcritical.com \\
\hline & & 37. www.webhosting.coop & 37. www.mediacoop.ca & 35. & www.privacyco-op.com \\
\hline & & 38. www.webtv.coop & 38. www.newscoopyyc.coop & 36. & www.rchain.coop \\
\hline & & & 39. www.lesoiseauxdepassage. & 37. & www.robinhoodcoop.org \\
\hline & & & coop & 38. & www.somconnexio.coop \\
\hline & & & 40. www.parti.coop & 39. & www.zerodark.coop \\
\hline & & & 41. www.positivenews.org.uk & & \\
\hline & & & 42. www.pueblo.global & & \\
\hline & & & 43. www.share.coop & & \\
\hline & & & 44. www.signco.io & & \\
\hline & & & 45. www.sommobilitat.coop & & \\
\hline & & & 46. www.tapazz.com & & \\
\hline & & & 47. www.vientos.coop & & \\
\hline & & & 48. www.weco.io & & \\
\hline & & & 49. www.wehelpen.nl & & \\
\hline & & & 50. www.kolyma2.de & & \\
\hline
\end{tabular}


Table 5. City-Regional Fieldwork Action Research.

\begin{tabular}{|c|c|c|c|}
\hline & \multicolumn{3}{|c|}{ City-Regional Fieldwork Action Research [32] } \\
\hline & $\begin{array}{l}\text { Tallinn } \\
\text { (Estonia) }\end{array}$ & $\begin{array}{c}\text { Barcelona } \\
\text { (Catalonia, Spain) }\end{array}$ & $\begin{array}{c}\text { Glasgow } \\
\text { (Scotland, UK) }\end{array}$ \\
\hline Potentially Pushed by & Public Sector & Civil Society & Private Sector \\
\hline Context & $\begin{array}{l}\text { Estonia has developed an efficient, secure, } \\
\text { and transparent digital society that } \\
\text { provides online government services } \\
\text { (e-services) to citizens, resulting in time } \\
\text { and cost savings. } \\
\text { This society is made possible by a data } \\
\text { exchange layer, called X-Road, which lets } \\
\text { government agencies gather citizens' data } \\
\text { just once and securely exchange them } \\
\text { among agencies instead of requesting them } \\
\text { from citizens many times. } \\
\text { Nonetheless, how are citizens responding } \\
\text { to this leading role of the public sector? } \\
\text { Besides, has the snowball effect of Skype's } \\
\text { founders investing money in emerging } \\
\text { Estonian start-ups facilitated any kind of } \\
\text { co-operative experience from below? }\end{array}$ & $\begin{array}{l}\text { Barcelona has demonstrated since } 2015 \\
\text { how the smart city policy agenda could be } \\
\text { modified by formulating } \\
\text { citizen-centric strategies. } \\
\text { - However, how sustainable are the } \\
\text { initiatives implemented under the banner } \\
\text { of platform and data co-operatives? }\end{array}$ & $\begin{array}{l}\text { A vast landscape of institutions is currently } \\
\text { working on digital transformations, } \\
\text { particularly around Glasgow and its } \\
\text { metropolitan surroundings. } \\
\text { Preliminary fieldwork research evidence } \\
\text { reveals that key stakeholders could } \\
\text { perceive this phenomenon as emerging due } \\
\text { to the historical grassroots movements in } \\
\text { the urban environment of Glasgow, and the } \\
\text { existing traditional co-operative ecosystem. }\end{array}$ \\
\hline Key stakeholders & $\begin{array}{ll}\text { - } & \text { University of Tallinn: School of } \\
\text { - } & \text { Digital Technologies } \\
\text { - } & \text { Estonian Co-operation Assembly Knowledge Estonia }\end{array}$ & $\begin{array}{ll}\text { - } & \text { Barcelona City Council: Social and } \\
\text { - } & \text { Solidarity Economy } \\
& \text { Barcelona City Council: Technology and } \\
\text { Digital Innovation Office/Cities Coalition } \\
\text { for Digital Rights (CCDR) } \\
\text { - } \quad \text { DECODE/DECIDIM/METADECIDIM } \\
\text { - UOC: IN3 } \\
\text { - UOC: Digital Commons (DIMMONS) } \\
\text { Federación de Co-operativas de Trabajo } \\
\text { de Catalunya }\end{array}$ & $\begin{array}{ll}\text { - } & \text { Scottish Tech Army } \\
\text { - } & \text { Scotland 5G Centre } \\
\text { - } & \text { Glasgow City Council } \\
\text { - } & \text { The DataLab } \\
\text { - } & \text { Scottish Cities Alliance } \\
\text { - } & \text { Urban Big Data Centre } \\
\text { - } & \text { Data Driven Innovation } \\
\text { - } & \text { Jdinburgh International Data Facility } \\
\text { - } & \text { DataFest } 2020 \\
\text { - } & \text { Scotland's AI Strategy } \\
\text { - } & \text { EDAS } \\
\text { - } & \text { Edinburgh Futures Institute }\end{array}$ \\
\hline
\end{tabular}


Table 5. Cont

\begin{tabular}{|c|c|c|c|}
\hline & \multicolumn{3}{|c|}{ City-Regional Fieldwork Action Research [32] } \\
\hline & $\begin{array}{c}\text { Tallinn } \\
\text { (Estonia) }\end{array}$ & $\begin{array}{c}\text { Barcelona } \\
\text { (Catalonia, Spain) }\end{array}$ & $\begin{array}{c}\text { Glasgow } \\
\text { (Scotland, UK) }\end{array}$ \\
\hline Potentially Pushed by & Public Sector & Civil Society & Private Sector \\
\hline Historical path-dependency & $\begin{array}{l}\text { Tallinn is remarkable in showing the way } \\
\text { to lead in public service provision and in } \\
\text { the interaction with citizens. } \\
\text { But how active are citizens in Tallinn as } \\
\text { regards self-organizing data-driven } \\
\text { activities such as platform and } \\
\text { data co-operatives? }\end{array}$ & $\begin{array}{l}\text { The libertarian municipal spirit, now } \\
\text { branded as new municipalism, within the } \\
\text { metropolitan networked city of Barcelona, } \\
\text { has always been the seed for } \\
\text { grassroots-driven resilient initiatives. }\end{array}$ & $\begin{array}{l}\text { While the data and platform ecosystem is } \\
\text { spreading out and growing rather quickly, } \\
\text { platform and data co-operatives remain so } \\
\text { far as niche experiments. }\end{array}$ \\
\hline $\begin{array}{l}\text { Current and active } \\
\text { co-operatives }\end{array}$ & $\begin{array}{l}\text { Fieldwork revealed that it could expect ab } \\
\text { rand new generation of co-operatives due } \\
\text { to the abundant local kickstartups, design } \\
\text { labs, hackathons, and initiatives at the } \\
\text { district level being pushed by several } \\
\text { key stakeholders. }\end{array}$ & $\begin{array}{ll}\text { Fieldwork revealed several initiatives: } \\
\text { - } \quad \text { www.saluscoop.org } \\
\text { - } \quad \text { www.colectic.coop } \\
\text { - } \quad \text { www.prosume.io } \\
\text { - } \quad \text { www.sommobilitat.coop } \\
\text { - } \quad \text { www.coopdevs.org } \\
\text { - } \quad \text { www.somatuma.org } \\
\text { - } \quad \text { www.femprocomexion.coop } \\
\text {. }\end{array}$ & $\begin{array}{l}\text { - } \quad \text { Fieldwork revealed these initiatives: } \\
\text { - } \quad \text { www.formandfunction.coop } \\
\text { - } \quad \text { www.graphics.coop } \\
\quad \text { wwaltspacecoop.co.uk }\end{array}$ \\
\hline
\end{tabular}




\subsection{Delphi Method}

The summary of the Delphi method, presented in Table 1, is based on distinguishing three main intertwined paradigms, as follows:

(i) P2P and the Commons by Michel Bauwens [124-126], who leads the www.p2pfoundation.net project;

(ii) Platform Co-operatives by Trebor Scholz [7,8,37,39], who coordinates the www.platform.coop main projects, with several related sub-projects at www.ioo.coop/directory, www.whoowntheworld.org, and www.platformobservatory.eu. Most recently, Scholz, from the New School of New York, Institute for the Co-operative Digital Economy (ICDE), has partnered with the well-known Mondragon Co-operative Corporation [24] (www.mondragon-corporation.com) to launch the first online course on platform co-operatives worldwide. The Mondragon Co-operative Corporation is the most popular and largest industrial co-operative experience and has been based in the Basque Country since 1956;

(iii) Data Co-operatives by Thomas Hardjono and Alex Pentland at MIT [41,45,127].

Under the Delphi method, key authors such as Bauwens, Scholz, Schneider, Hardjono, and Pentland were approached as the current main experts in the field of platform and data co-operatives, to crystallize the trends of digital co-operativism. The interviews revolved around how COVID-19's undoubtedly deep socio-economic impact may affect strategies to develop new or alternative socio-economic co-operative initiatives. Although AI is actually intensifying automation at work [83], some hegemonic projects are being re-oriented or reversed, according to these experts. Actually, the success of the online course on platform co-operatives jointly launched by the New School and the Mondragon Co-operative Corporation seems to offer evidence of how platform and data co-operatives will move post-pandemic. However, the research reveals clear differences among the experts' economic paradigms, as follows: while Bauwens advocated an ethical economy, Scholz advocated an entrepreneurial economy. Hardjono entirely focused on his conceptualization of a data-driven economy. Interestingly, as shown in Table 1, each of them suggested different good practices for platform and data co-operatives, which this paper later classifies according to taxonomy (Table 4).

\subsection{Taxonomy for Platform and Data Co-operatives}

The Delphi method showed a total consensus on the relationship between platform and data co-operatives: according to Bauwens [125], Scholz [8], and Hardjono and Pentland [41], data co-operatives can be seen as a subcategory of platform co-operatives. Generally speaking, this article finds that data co-operatives focus merely on data stores, while platform co-operatives revolve around the whole business model of workers, services, and products, which also includes data.

There is a diverse set of taxonomies, as follows [37]:

- Broadly, platform co-operatives focus on business models, while data co-operatives mutualize and store data;

- Regarding flow, platform co-operatives manage labor exchange and distribute content while aggregating the data of some members/citizens.

Finally, platform co-operatives consist of four typologies-

(i) Consortia Worker Platforms:

Co-operatively owned online labor brokerages and marketplaces. This co-operative is the most common platform. Workers/citizens own the company, receive dividends, and have an input in running the company;

Union-backed labor platforms. Unionized workers/citizens can create their own companies as a result of the collaboration between unions and workers. 
(ii) Producer-led Platforms (as the merge of users and producers). Users and producers own the platform, through which producers can sell their work;

(iii) Multistakeholder/Community Platforms:

- City-owned platforms. This model in practice would involve a collaboration between a large number of cities, which would pool their resources to create a software platform for any kind of service-short-term rentals, utilities, and so on (e.g., CCDR);

Co-operatives from within. This case exists when workers/citizens from a sharing economy platform like Uber use the technical infrastructure of the company to run their own enterprise. Worker co-operatives form inside the belly of the sharing economy (Mensakas).

(iv) Data co-operatives can be considered a sub-typology of platform co-operatives, also known as data consortia platforms.

To further simplify the analysis, four typologies for platform co-operatives are defined as stemming from the triangulation technique, as follows:

(i) Worker-this typology refers to the flow of labor exchange and revolves around co-operativizing work (stemming from mobility services);

(ii) Producer (a merging of users and producers) - this typology refers to the flow of content distribution and revolves around co-operativizing the outcome, resulting in the exchange between users and producers (stemming from culture, agriculture, food, software, websites, hosting, start-up support, videoconferencing, etc.);

(iii) Multistakeholder-this typology refers to the flow of content distribution and revolves around co-operativizing community services (stemming from healthcare, delivery riders, media, rental, housing, land, etc.);

(iv) Data (this fits into data co-operatives) - this typology refers to the flow of data aggregation and revolves around co-operativizing and mutualizing data (particularly data related to finance, health, security, etc.).

\subsection{Identification of Cases by Typology}

As a result of the Delphi method, the triangulation technique identified 302 cases overall in the \#PlatformCoop directory at https://ioo.coop/directory/. The directory distinguishes between two main categories:

- Platform co-operatives-within this category, data co-operatives are embedded as a subcategory. Out of 302 cases, $156(52 \%)$ were identified as platform co-operatives, and inside those cases, data co-operatives accounted for 39 (25\%) of the 156;

- Ecosystem - the remaining cases were embryonic initiatives that might become platform or data co-operatives $(48 \%)$ or simply disappear, or have already disappeared.

This article has left aside the ecosystem category by focusing on platform co-operatives (and data co-operatives). Thus, Table 4 illustrates a classification of each platform co-operative according to its typology. Several cases could be included in multiple typologies, but the identification process aimed to include each case in only one typology. In light of the results, the typologies each accounted for the following percentages of the total cases:

(i) Worker Platform Co-operatives represented 19\%;

(ii) Producer Platform Co-operatives represented 24\%;

(iii) Multistakeholder Platform Co-operatives represented 32\%;

(iv) Data Platform Co-operatives represented 25\%. 
Generally speaking, the taxonomy sheds light on the linkage between the potential vulnerabilities faced by pandemic citizens post-COVID-19 and the relatively higher number of platform co-operatives-namely multistakeholder co-operatives-offering community services including healthcare, delivery riders, media, rental, housing, etc. According to the OECD, co-operatives can develop a much larger role post-COVID-19 to inspire transformation, at the multistakeholder level within communities, toward a more inclusive and sustainable economy and society [128]. Based on Table 4, it seems that the typology of the multistakeholder-driven platform co-operative-actually the hegemonic typology—is most likely to benefit a post-pandemic world.

\subsection{Territorial Fieldwork Analysis in Three European City-Regions}

As the last step of the triangulation technique, after the Delphi method and the identification of cases through typologies, this article carried out fieldwork action research by interviewing several key stakeholders in three European city-regions [32]. Primarily, this research aimed to gather evidence to support the response to the main research question. The selection of the three cases was entirely aligned with the assumption that Tallinn, Glasgow and Barcelona are respectively driven by the public sector, the private sector, and civil society. As such, this article looked into the following questions related to co-operatives: How are the leading roles of the public sector in Tallinn, the active civil society in Barcelona, and the regionally networked initiatives around Glasgow related to the formation of co-operatives? Do these initiatives hinder societies or help them flourish? Is there any contextual factor that determines the emergence of such initiatives into data or platform co-operatives? How could the historic path-dependency of co-operatives influence the potential emergence of initiatives?

Despite platform and data co-operatives essentially being virtual organizations operating in the digital space, from the beginning, this research has particularly focused on their essentially being territorially rooted, but techno-politically determined. Some of the data and platform co-operative cases researched may incentivize, respectively, platform-owning under a project-value scheme or data-sharing under a monetization scheme, through which citizens can share subsets of their data to earn money. However, other rewards-such as data dashboards (letting users explore their own data and even compare them with those of others) or being given access to new products and services-have also been identified. Data altruism is common in health (increasingly in mobility; related to multistakeholder and data-driven co-operatives' typologies) and research platforms, in which data donation is seen as serving the common good $[42,116]$.

As shown in Table 5, the city-regional fieldwork action research revealed the following results, by shedding light on the research question:

(i) Tallinn is eminently an innovative city in terms of digital policy and active entrepreneurship in the public sector, and fieldwork revealed that it could expect a new brand generation of co-operatives as a result of the dynamism of the local ecosystem. However, the interviewee acknowledged some reluctance toward co-operatives due to the historic Soviet legacy. The current strategic pathway has started to show prominent initiatives, such as Open Knowledge Estonia, that may be insightful in the near future. Fieldwork research also revealed the substantial role that Estonia Co-operation Assembly is playing in incentivizing initiatives from the civil society, still very much grounded in niche entrepreneurial domains. Not surprisingly though, interviewees anticipated a collective action to share data, gather data collectively, or even own platforms as a response to the COVID-19 crisis, possibly in line with the successful initiative called Scottish Tech Army currently taking place in Glasgow;

(ii) Glasgow showed a rich and highly emergent digital landscape, increasingly pushed by post-COVID-19 momentum, with not only outstanding initiatives such as the Scottish Tech Army but also cutting-edge sites such as Scotland 5G Centre. Though fieldwork revealed a growing awareness driven by the private sector, it remains to be seen how and when co-operatives may start entering into this fertile digital landscape. Thus, it seems a matter of time before we observe an emergence of platform and data co-operatives in this city-regional location, as a result 
of a proliferation of a large amount of initiatives that may determine the position of Glasgow as a new member of the CCDR;

(iii) Barcelona, as a city equipped with a libertarian municipalist spirit, is well positioned to lead the platform and data co-operative field in Europe. As interviews revealed, Barcelona, being the chief city of the CCDR, may well make a strong case in the post-COVID-19 era for encouraging pandemic citizens to establish co-operatives in the healthcare system, such as the successful case of Salus Coop. It goes without saying that the strategic program known as DECODE-DECIDIM-METADECIDIM that has assisted Barcelona since 2015 was clearly mentioned by interviewees as the source of the digital transformation process occurring in the city-region. Furthermore, the ongoing networking activities of the CCDR at the international level, related to AI, data commons, and city-to-city-learning, may well establish Barcelona among the rest of the 41 global city-regions in a leading position for influencing smart city policies that could protect European "pandemic citizens"' digital rights. Consequently, Barcelona's position will likely foster platform and data co-operatives in the near future.

\section{Conclusions}

This ongoing exploratory action research intended to decipher the rationale behind platform and data co-operatives amidst the new citizenship regime, which this article presents as the novel European "pandemic citizenship." In doing so, this article's state-of-the-art elaboration on this citizenship regime links it with the platform and data co-operatives phenomenon, using an action research triangulation technique from the perspective of social innovation to grasp research and policy evidence in response to the research question [121].

In response to the research question, the expert interpretations and evidence-based identification of cases may suggest an ongoing trend towards interest in co-operatives as a result of the COVID-19 crisis being seen as a turning point for citizens in Europe. With a broad range of cases that may well fit into urgent communitarian needs, it is still early to predict whether platform and data co-operatives could alter existing data governance extractivism $[28,63]$. On the other hand, it seems more likely than ever before that European pandemic citizens may be more techno-politically aware of the increasing datafication of their lives. Eventually, anticipating an inexorable pandemic recession, the formation of platform and data co-operatives may result in claims being made on citizens' digital and labor rights by a large number of institutions and organizations.

Therefore, regarding the first hypothesis, COVID-19 has effectively invigorated the interest in co-operatives. However, as the fieldwork research in the three European city-regions shows (Tallinn, Glasgow, and Barcelona), platform co-operatives are still created randomly by entrepreneurial prerogative, without following a certain pattern of development from the public sector, the private sector, or even civil society.

Contrary to the first hypothesis, data co-operatives may well benefit from the pan-European post-GDPR policy response (second hypothesis). The European Commission has already established the European Strategy for Data, regulating European pools of data sharing between the public and private sectors through data ecosystems to protect citizens' digital rights [62], and a possible Data Act in 2021 would set up a legislative framework for data governance. It remains to be seen whether city-regional authorities could establish data co-operatives with fiduciary obligations to their members. By opening up access to public datasets across Europe, data co-operatives may well represent a key component of the European Strategy for Data. At the heart of data co-operatives may be federated cloud-based modeling and simulation platforms that (i) provide access to data, (ii) enable application development and the integration of users' own data, and (iii) give access to vast amounts of natural and socio-economic information. Several initiatives in this direction are already emerging, which inevitably may alter the current existing relationship between "pandemic citizens" and data: (i) SOLID (https://solid.mit.edu), which supports the seamless access, use, and re-use of data, and trust oin data sources; (ii) Coopedia (https://coopedia.starter.coop), which is a co-operative developed by 
Cooperatives Europe [84] based in France that operates as a new open source software that stems from SOLID; (iii) Hubl (https://hubl.world), which is a tool that connects freelance communities.

It goes without saying that the practical implications and contributions of this article need to be verified via the contribution of robust theoretical evidence. According to the established academic stance of the Foundational Economy (https://foundationaleconomy.com), platform and data co-operatives may alter existing data governance extractivism in the post-COVID-19 era if (i) the government play a leading role in crisis provisioning, (ii) businesses behave co-operatively, and (iii) civil society and the effectiveness of local community solidarity provides strong social capital for "pandemic citizens." Moreover, according to this academically interesting contribution, platform and data co-operatives should focus on the foundational transformations needed in (i) health and care, (ii) housing and energy, (iii) food, (iv) social care and licensing, (v) tax reform, (vi) pension funds and the insurance provision of material infrastructure, (vii) life and work transition plans for local urban and rural areas, (viii) governments' capacity building, and (ix) global solidarity.

In summary, this article concludes with four aspects that frame potential future research and a policy agenda for platform and data co-operatives.

First, expert analyses, case identification (with most cases of co-operativizing community services in line with the emergent need created by the threat of the coronavirus) and preliminary fieldwork action research have demonstrated that the post-COVID-19 world is reigniting the need to reactivate European civil societies by further experimenting with digital socio-economic innovations, such as platform and data co-operatives-but marginally and on a small scale. Further research is needed to better understand how this reaction could be reinforced if it became an organic phenomenon and translocally spread to connect several European city-regional locations.

Second, by linking up the European pandemic citizenship regime and co-operative formation, the fieldwork research, through interviewing experts (via the Delphi method), suggesting a taxonomy of four typologies and identifying 156 platform and data co-operatives, and exploring the territorial preconditions in three European city-regions, reveals the following conclusions. First, even in the aftermath of COVID-19, there is very little understanding about the scope and functioning of co-operatives, with clear exceptions due to historical factors such as those in Barcelona. Second, in the cases of Tallinn and Glasgow, we observed that despite the fertile digital ecosystems and institutional and business support, existing digital infrastructures composed of European pandemic citizens are relatively poor or absent as regards co-operative formation. Third, ultimately, according to several experts, the difficulties in accessing start-up capital for co-operative entrepreneurs and activists are remarkable. However, as the documentary "Reclaiming Work" shows [129], European pandemic citizens have clearly reacted in several cities, subverting the extractive logic of the gig economy by imitating the code of Deliveroo and creating and sharing their own open source code and infrastructure for CoopCycle (cloning the logistic software and an e-commerce system adapted for bike deliveries).

Third, fieldwork action research found that procurement and public incentives are required to push ahead, enhance, and reinforce platform and data co-operatives beyond extremely marginal experiments aligned with data donation and altruism. EU funding for research and innovation should be more accessible to civil society organizations and platform co-operatives-such as Kolyma2, created by former workers of Deliveroo in Berlin in the aftermath of COVID-19-to establish alternatives for transitioning the platform economy to a post-capitalist world. The sustainability of such alternatives shows the viability of publicly financed open source software platforms, that do not belong to a private entity but can be used by other platform or data co-operatives-with a software protected by Copyleft license-and can fit the definition of a social economy according to the EU.

Fourth, consequently and ultimately, initiatives around platform and data co-operatives need to find their own strategic pathways amidst the digital and social economy policy agenda of the European Commission. The ongoing institutional arrangements of H2020-Smart Cities and Communities have already gathered 17 lighthouse projects (encompassing 46 lighthouses and 71 fellow cities), and the still-experimental Digital Innovation Hubs follow the new European Data Strategy in its 
entirety $[33,111]$. These initiatives can likely foster firm city-regional connections between social entrepreneurs and urban activists in the pursuit of scaling up platforms and data co-operatives to better articulate the uneven European post-COVID-19 citizenship. These digital co-operatives can play a crucial part in setting up new the European realities of workplace democracy and the organization of pandemic workers.

In sum, this article found that there has been an uneven reaction to the COVID-19 crisis. Co-operatives (platform-based or data-driven) portray a potential alternative for altering existing extractivist data governance models in cities and regions through technological sovereignty and inter-connected data ecosystems $[62,130,131]$. It remains to be seen, however, whether the promises and perils of platform and data co-operatives permit European pandemic citizenship in at least the regaining of human dignity (rescuing digital, labor, and democratic citizens' rights)—something this crisis, as nothing before in such a direct form, may have severely damaged forever [132].

Funding: This research was funded by H2020-SCC-691735-REPLICATE and ESRC under the Grant Urban Transformations program ES/M010996/1.

Acknowledgments: The author is deeply indebted to the experts in the Delphi Method (particularly Bauwens and Scholz that kindly contributed to this study) and to stakeholders interviewed for the fieldwork action research for the case studies of Barcelona, Glasgow, and Tallinn. Special thanks to Max Craglia.

Conflicts of Interest: The author declares no conflict of interest.

\section{References}

1. Kapecki, T. Elements of sustainable development in the context of the environmental and financial crisis and the COVID-19 pandemic. Sustainability 2020, 12, 6188. [CrossRef]

2. McKinsey. The Future of Work. Available online: https://www.mckinsey.com/featured-insights/future-ofwork/the-future-of-work-in-europe?cid=soc-web\# (accessed on 1 July 2020).

3. MIT. The Work of the Future: Shaping Technology and Institutions; MIT Work of the Future: Cambrigde, MA, USA, 2019.

4. Moradi, P.; Levy, K. The Future of Work in the Age of AI: Displacement or Risk-Shifting? In The Oxford Handbook of Ethics of AI; Dubber, M.D., Pasquale, F., Das, S., Eds.; Oxford University Press: Oxford, UK, 2020; pp. 1-20. [CrossRef]

5. Orlik, J. Workers Are Struggling to Adapt to an Uncertain World. Available online: https://www.nesta.org. uk/blog/workers-are-struggling-adapt-uncertain-world/ (accessed on 1 July 2020).

6. Pierantoni, I.; Pierantozzi, M.; Sargolini, M. COVID 19-A qualitative review for the reorganisation of human living environments. Appl. Sci. 2020, 10, 5576. [CrossRef]

7. Scholz, T. Digital Labor: The Internet as Playground and Factory; Routledge: New York, NY, USA; London, UK, 2013.

8. Scholz, T. Uberworked and Underpaid: How Workers Are Disrupting the Digital Economy; Polity Press: Cambridge, UK, 2017.

9. WEF (World Economic Forum). Chater of Principles for Good Platform Work; WEF: Geneva, Switzerland, 2019.

10. Calzada, I. Emerging Citizenship Regimes and Rescaling (European) Nation-States: Algorithmic, Liquid, Metropolitan and Stateless Citizenship Ideal Types. In Handbook on the Changing Geographies of the State: New Spaces of Geopolitics; Moisio, S., Koch, N., Jonas, A.E.G., Lizotte, C., Luukkonen, J., Eds.; Edward Elgar: Cheltenhman, UK; Northampton, MA, USA, 2020. [CrossRef]

11. Barns, S. Platform Urbanism: Negotiating Platform Ecosystems in Connected Cities; Springer: Singapore, 2020.

12. Syed, I.U.B. Labor exploitation and health inequalities among market migrants: A political economy perspective. J. Int. Migr. Integr. 2015, 17, 449-465. [CrossRef]

13. Stucke, M.E. Should We Be Concerned about Data-opolies? 2 Georget. Law Technol. Rev. 2018, 275. [CrossRef]

14. Belloc, F. Why Isn't Uber Worker-Managed? A Model of Digital Platform Cooperatives; CESifo Working Papers No. 7708; University of Siena: Siena, Italy, 2019.

15. De Marco, C.E.; Di Minin, A.; Marullo, C.; Nepelski, D. Digital Platform Innovation in European SMEs: An Analysis of SME Instrument Business Proposals and Case Studies; Publications Office of the European Union: Luxembourg, 2019. 
16. Digital Future Society. The Future of Work in the Digital Era: The Rise of Labour Platforms; DFS: Barcelona, Spain, 2019.

17. Fairwork Foundation. How Is the Platform Economy Responding to COVID-19? Open Democracy. Available online: https://www.opendemocracy.net/en/oureconomy/how-platform-economy-respondingcovid-19/ (accessed on 1 July 2020).

18. Helberger, N.; Pierson, J.; Poell, T. Governing online platforms: From contested to cooperative responsibility. Inf. Soc. 2018, 34, 1-14. [CrossRef]

19. Kilhoffer, Z.; de Groen, W.P.; Lenaerts, K.; Smits, I.; Hauben, H.; Waeyaert, W.; Giacumacatos, E.; Lhernould, J.-P.; Robin-Olivier, S. Study to Gather Evidence on the Working Conditions of Platform Workers; European Commission: Brussels, Belgium, 2019.

20. Lane, M. Regulating Platform Work in the Digital Age. Going Digital Toolkit Policy Note, No. 1. 2020. Available online: https://goingdigital.oecd.org/toolkitnotes/regulating-platform-work-in-the-digital-age.pdf (accessed on 1 July 2020).

21. Riso, S. Digital Age: Mapping the Countours of the Platform Economy; Eurofound: Dublin, Ireland, 2020.

22. Stehlin, J.; Hodson, M.; McMeekin, A. Platform Mobilities and the Production of Urban Space: Toward a Typology of Platformization Trajectories. In Environment and Planning A: Economy and Space; Sage Publications: Thousand Ouks, CA, USA, 2020. [CrossRef]

23. Taylor, A. The People's Platform: Taking Back Power and Culture in the Digital Age; Metropolitan Books: New York, NY, USA, 2020.

24. Calzada, I. Knowledge Building and Organizational Behavior: The Mondragon Case from a Social Innovation Perspective. In International Handbook on Social Innovation: Collective Action, Social Learning and Transdisciplinary Research; Moulaert, F., MacCallum, D., Mehmood, A., Hamdouch, A., Eds.; Edward Elgar: Cheltenhman, UK; Northampton, MA, USA, 2013; pp. 219-229. [CrossRef]

25. Gupta, C. The Co-Operative Model as a 'Living Experiment in Democracy'. J. Co-Oper. Organ. Manag. 2014, 2, 98-107. [CrossRef]

26. Moulaert, F.; MacCallum, D. Advanced Introduction to Social Innovation; Edward Elgar: Cheltenham, UK, 2019.

27. Calzada, I. Will Covid-19 Be the End of the Global Citizen? Apolitical. Available online: https://apolitical.co/ en/solution_article/will-covid-19-be-the-end-of-the-global-citizen (accessed on 1 July 2020).

28. Morozov, E. The Tech 'Solutions' for Coronavirus Take the Surveillance State to the Next Level'. Available online: https://www.theguardian.com/commentisfree/2020/apr/15/tech-coronavirus-surveilancestate-digital-disrupt (accessed on 1 July 2020).

29. Zuboff, S. The Age of Surveillance Capitalism: The Fight for a Human Future at the New Frontier of Power; Profile: London, UK, 2019.

30. Berditchevskaia, A.; Baeck, P. The Future of Minds and Machines: How Artificial Intelligence Can Enhance Collective Intelligence; NESTA: London, UK, 2020.

31. Bigo, D.; Isin, E.; Ruppert, E. Data Politics; Routledge: London, UK, 2019.

32. Calzada, I. Benchmarking future city-regions beyond nation-states. Reg. Stud. Reg. Sci. 2015, 2, 351-362. [CrossRef]

33. Calzada, I. Smart City Citizenship; Elsevier Science Publishing Co Inc.: Cambridge, MA, USA, 2020; ISBN 978-0-12-815300-0.

34. Borkin, S. Platform Co-Operatives—Solving the Capital Conumdrum; NESTA: London, UK, 2019.

35. Cherry, M. Legal and Governance Structures Built to Share: The Rise of Platform Co-Operatives; Legat Studies Research Paper Series; Saint Louis University School of Law: Saint Louis, MO, USA, 2016.

36. McCann, D.; Yazici, E. Disrupting Together: The Challenges (and Opportunities) for Platform Co-Operatives; NEF: London, UK, 2018.

37. Scholz, T. Platform Cooperativism: Challenging the Corporate Sharing Economy; Rosa Luxemburg Stiftung: New York, NY, USA, 2016.

38. Schneider, N. An Internet of ownership: Democratic design for the online economy. Sociol. Rev. 2018, 66, 320-340. [CrossRef]

39. Scholz, T.; Schneider, N. Ours to Hack and to Own; OR Books: New York, NY, USA, 2017.

40. Blasimme, A.; Vayena, E.; Hafen, E. Democratizing health research through data cooperatives. Philos. Technol. 2018, 31, 473-479. [CrossRef]

41. Hardjono, T.; Pentland, A. Data cooperatives: Towards a foundation for decentralized personal data management. arXiv 2019, arXiv:1905.08819. 
42. Hafen, E. Personal Data Cooperatives-A New Data Governance Framework for Data Donations and Precision Health. In The Ethics of Medical Data Donation; Krutzinna, J., Floridi, L., Eds.; Springer International Publishing: Cham, Switzerland, 2019; pp. 141-149.

43. Hafen, E.; Kossmann, D.; Brand, A. Health data cooperatives: Citizen empowerment. Methods Inf. Med. 2014, 53, 1-5.

44. Mòdol, J.R. Citizens' Cooperation in the Reuse of Their Personal Data: The Case of Data Cooperatives in Healthcare. In Collaboration in the Digital Age: How Technology Enables Individuals, Teams and Businesses; Riemer, K., Schellhammer, S., Meinert, M., Eds.; Springer International Publishing: Cham, Switzerland, 2019; pp. 159-185.

45. Pentland, A.; Hardjono, T.; Penn, J.; Colclough, C.; Ducharmee, B.; Mandel, L. Data Cooperatives: Digital Empowerment of Citizens and Workers; MIT Connnection Science: Boston, MA, USA, 2019.

46. International Co-operative Alliance. Co-Operative Governance Fit to Build Resilience in the Face of Complexity; Report, 2015; International Co-operative Alliance: Brussels, Belgium, 2015.

47. Bengu, R. What Can South Africa Learn from Mondragon? The Answer Lies in Community Ownership. Available online: https:/www.dailymaverick.co.za/article/2018-10-26-what-can-south-africa-learn-frommondragon-the-answer-lies-in-community-ownership/ (accessed on 1 July 2020).

48. Clamp, C.A.; Innocentus, A. Social entrepreneurship in the Mondragon Co-Operative Corporation and the challenges of successful replication. J. Entrep. 2010, 19, 149-177. [CrossRef]

49. Ellerman, D.P. Entrepreneurship in the Mondragon Cooperatives. Rev. Soc. Econ. 1984, 42, 272-294. [CrossRef]

50. Heales, C.; Hodgson, M.; Rich, H. Humanity at Work: Mondragon, a Social Innovation Ecosystem Case Study; The Young Foundation: London, UK, 2017.

51. Apolitical. The Italian Region Where 30\% of GDP Comes from Cooperatives. Available online: https://apolitical.co/en/solution_article/italian-region-30-gdp-comes-cooperatives (accessed on 1 July 2020).

52. Battilani, P.; Zamagni, V. The Managerial Transformation of Italian Co-Operative Enterprises 1946-2010. Bus. Hist. 2012, 54, 964-985. [CrossRef]

53. Borzaga, C.; Galera, G. The concept and practice of social entreprise. Lesson from the Italian experience. Int. Rev. Soc. Res. 2012, 2, 85-102. [CrossRef]

54. Gonzales, V. Italian social cooperatives and the development of civic capacity: A case of cooperative renewal? Affin. A J. Radic. Theory Cult. Action 2010, 4, 225-251.

55. Menzani, T.; Zamagni, V. Cooperative networks in the Italian economy. Enterp. Soc. 2010, 11, 98-127. [CrossRef]

56. Schneider, N. Tech New Deal: Policies for Community-Owned; University of Colorado Boulder: Boulder, CO, USA, 2020.

57. Dixson-Declève, S. Protect, Prepare and Transform Europe: Recovery and Resilience Post Covid-19; Publications Office of the European Union: Luxembourg, 2020.

58. Eubanks, V. Automating Inequality: How High-Tech Tools Profile, Police, and Punish the Poor; St. Martin's Press: New York, NY, USA, 2017.

59. Dyer-Witheford, N. Left populism and platform capitalism. Triple C: J. A Glob. Sustain. Inf. Soc. 2020, 18, 116-131. [CrossRef]

60. Delacroix, S.; Lawrence, N.D. Bottom-up Data Trusts: Disturbing the 'One Size Fits All' Approach to Data Governance. Int. Data Priv. Law 2019, 9. [CrossRef]

61. Duran, X. El Imperio de los Datos; Universitat de Valencia: Valencia, Spain, 2019.

62. Calzada, I.; Almirall, E. Data ecosystems for protecting European citizens' digital rights. Transform. Gov. People Process Policy 2020, 14, 133-147. [CrossRef]

63. Morozov, E. Digital Socialism? The calculation debate in the age of big data. New Left Rev. 2019, 116, 33-67.

64. Dyer-Witherford, N.; Kjosen, M.; Steinhoff, J. Inhuman Power: Artificial Intelligence and the Future of Capitalism; Pluto Press: London, UK, 2019.

65. Hand, D.J. Dark Data; Princeton University Press: Princeton, NJ, USA, 2020.

66. Misuraca, G.; van Noordt, C. Overview of the Use and Impact of AI in Public Services in the EU; Publications Office of the European Union: Luxembourg, 2020.

67. Wong, P.-H. Cultural differences as excuses? Human rights and cultural values in global ethics and governance of AI. Philos. Technol. 2020. [CrossRef]

68. Rikap, C. Amazon: A story of accummulation through intellectual rentiership and predation. Compet. Change 2020. [CrossRef] 
69. Vinuesa, R.; Azizpour, H.; Leite, I.; Balaam, M.; Dignum, V.; Domisch, S.; Felländer, A.; Langhans, S.D.; Tegmark, M.; Fuso Nerini, F. The role of artificial intelligence in achieving the SDGs. Nat. Commun. 2020, 11, 223. [CrossRef] [PubMed]

70. Democratizing Work. Available online: www.democratizingwork.org (accessed on 1 July 2020).

71. Saltelli, A.; Bammer, G.; Bruno, I.; Charters, E.; Di Fiore, M.; Didier, E.; Espeland, W.N.; Kay, J.; Lo Piano, S.; Mayo, D.; et al. Five ways to ensure that models serve society: Manifesto. Nature 2020, 582, 483-484. [CrossRef]

72. Beckett, A. The New Left Economics: How a Network of Thinkers Is Transforming Capitalism. Available online: https://www.theguardian.com/news/2019/jun/25/the-new-left-economics-how-a-networkof-thinkers-is-transforming-capitalism (accessed on 1 July 2020).

73. Alosi, A. Commoditized workers: Case study research on labor law issues arising from a set of on-demand/gig economy platforms. Comp. Labor Law Policy J. 2016, 37, 653-690.

74. Hayes, R. Worker-Owned Apps Are Trying to Fix the Gig Economy's Exploitation; Motherboard, Tech by Vice: Montreal, QC, Canada, 2019.

75. Lutz, C. Digital inequalities in the age of artificial intelligence and big data. Hum. Behav. Emerg. Technol. 2019, 1, 141-148. [CrossRef]

76. Woodcock, J.; Graham, M. The Gig Economy: A Critical Introduction; Polity: London, UK, 2019.

77. Gillespie, T. The politics of 'platforms'. New Media Soc. 2020, 12, 347-364. [CrossRef]

78. DiEM25. Technological Sovereignty: Democratising Technology and Innovation; Green Paper No. 3; DIEM25: Brussels, Belgium, 2018.

79. Luxemburg, R. Reform or Revolution. Militant Publications: London. 1900. Available online: https: //www.marxists.org/archive/luxemburg/1900/reform-revolution/ch07.htm (accessed on 1 July 2020).

80. Sandoval, M. Entrepreneurial Activism? Platform Cooperativism between Subversion and Co-Optation. Crit. Soc. 2019. [CrossRef]

81. Siapera, E.; Papadopoulou, L. Entrepreneurialism or Cooperativism? J. Pract. 2016, 10, 178-195. [CrossRef]

82. Mos, E. Digital Platforms and the (Re)Organization of Solidarity. Available online: https://platformlabor.net/ blog/digital-platforms-and-the-reorganization-of-solidarity (accessed on 1 July 2020).

83. Bastani, A. Fully Automated Luxury Communism; Verso: London, UK, 2019.

84. Cooperatives Europe. Available online: https://coopseurope.coop/resources/news/covid-19-coop-response (accessed on 1 July 2020).

85. Lee, J.Y.; Woods, O.; Kong, L. Towards More Inclusive Smart Cities: Reconciling the Divergent Realities of Data and Discourse at the Margins. Geogr. Compass 2020. [CrossRef]

86. Duarte, F.; Álvarez, R. The data politics of the urban age. Palgrave Commun. 2019, 5. [CrossRef]

87. Karpf, D. Two provocations for the study of digital politics in time. J. Inf. Technol. Politics 2020, 17, 87-96. [CrossRef]

88. O'Flaherty, K. Zoom's a Lifeline during COVID-19: This Is Why It's also a Privacy Risk. Available online: https://www.forbes.com/sites/kateoflahertyuk/2020/03/25/zooms-a-lifeline-during-covid19-this-is-why-its-also-a-privacy-risk (accessed on 1 July 2020).

89. The Online Meeting Co-operative. 2020. Available online: www.org.meet.coop (accessed on 1 July 2020).

90. Kitchin, R. Civil Liberties or Public Health, or Civil Liberties and Public Health? Using Surveillance Technologies to Tackle the Spread of Covid-19. Space Polity 2020, 1-20. [CrossRef]

91. Beroche, H. Urban AI, London. 2020. Available online: https://smartworld-ai.com/wp-content/uploads/2020/ 06/URBAN-AI-1.pdf (accessed on 30 September 2020).

92. Calzada, I. Algorithmic Nations: Seeing like a city-regional and techno-political conceptual assemblage. Reg. Stud. Reg. Sci. 2018, 5, 267-289. [CrossRef]

93. Bridle, J. Algorithmic citizenship, digital statelessness. Geohumanities 2016, 2, 377-381. [CrossRef]

94. Cheney-Lippold, J. A new algorithmic identity: Soft biopolitics and the modulation of control. Theory Cult. Soc. 2011, 28, 164-181. [CrossRef]

95. Palm, T. Perestroika in Estonia: The cooperatives. J. Balt. Stud. 1989, 20, 127-148. [CrossRef]

96. Datta, A. Self (Ie)-governance: Technologies of intimate surveillance in India under COVID-19. Dialogues Hum. Geogr. 2020. [CrossRef]

97. Lucas, E. Pandemic Democracy. Available online: https://www.cepa.org/pandemic-democracy (accessed on 1 July 2020). 
98. Pickard, V.W. Cooptation and cooperation: Institutional exemplars of democratic internet technology. New Media Soc. 2008, 10, 625-645. [CrossRef]

99. Aho, B.; Duffield, R. Beyond surveillance capitalism: Privacy, regulation and big data in Europe and China. Econ. Soc. 2020, 49, 187-212. [CrossRef]

100. DPO (Democratic Public Ownership). Democratic Digital Infrastructure; Common Wealth: London, UK, 2020.

101. Gekker, A.; Hind, S. Infrastructural surveillance. New Med. Soc. 2019, 1-23. [CrossRef]

102. Hintz, A.; Dencik, L.; Wahl-Jorgensen, K. Digital citizenship and surveillance society. Int. J. Commun. 2017, 11, 731-739.

103. MAIEI (Montreal AI Ethics Institute). The State of AI Ethics; MAIEI: Montreal, QC, Canada, 2020.

104. Calzada, I. Technological sovereignty: Protecting citizens' digital rights in the AI-driven and post-GDPR algorithmic and city-regional European realm. Reg. eZine 2019, 4. [CrossRef]

105. Arroyo, L.; Amjad, O.; Murillo, D. My Data, My Rules: From Data Extractivism to Digital Empowerment; ESADE, Institute for Social Innovation: Barcelona, Spain, 2019.

106. GaiaX. A Federated Data Infrastructure for Europe. Available online: www.data-infrastructure.eu (accessed on 1 July 2020).

107. Craglia, M. (Ed.) Artificial Intelligence: A European Perspective; European Commission-JRC: Luxembourg, 2018.

108. Craglia, M. (Ed.) Artificial Intelligence, a European Perspective: Lessons from the COVID-19 Crisis; European Commission-JRC: Luxembourg, 2020.

109. EPRS. Artificial Intelligence: From Ethics to Policy; STOA: Brussels, Belgium, 2020.

110. Calzada, I. (Smart) citizens from data providers to decision makers? The case study of Barcelona. Sustainability 2018, 10, 3252. [CrossRef]

111. Calzada, I. Replicating smart cities: The City-to-City Learning Programme in the Replicate EC-H2020-SCC Project. Smart Cities 2020, 3, 49. [CrossRef]

112. Neff, G.; McGrath, M.; Prakash, N. AI @ Work; OII: Oxford, UK, 2020.

113. Lnenicka, M.; Komarkova, J. Big and Open Linked Data Analytics Ecosystem: Theoretical Background and Essential Elements. Gov. Inf. Q. 2019, 36, 129-144. [CrossRef]

114. Oliveira, S.; Barros Lima, M.I.; Farias Lóscio, B. Investigations into Data Ecosystems: A Systematic Mapping Study. Knowl. Inf. Syst. 2019, 61, 589-630. [CrossRef]

115. Kostka, G. China's social credit systems and public opinion: Explaining high levels of approval. New Med. Soc. 2019, 21, 1565-1593. [CrossRef]

116. Beardman, S. Altruism and the Experimental Data on Helping Behavior. Ethical Theory Moral Pract. 2012, 15, 547-561. [CrossRef]

117. Blok, A.; Courmont, A.; Hoyng, R.; Marquet, C.; Minor, K.; Nold, C.; Young, M. Data Platforms and Cities. Tecnoscienza: Ital. J. Sci. Technol. Stud. 2017, 8, 175-219.

118. Como, E.; Mathis, A.; Tognetti, M.; Rapisardi, A. Cooperative platforms in a European landscape: An exploratory study. In Proceedings of the ISIRC Conference, Glasgow, UK, 1 September 2016.

119. Ho, C.; Chuangt, T. Governance of Communal Data Sharing. In Good Data; Daly, A., Devitt, K., Mann, M., Eds.; Institute of Network Cultures: Amsterdam, The Netherlands, 2019; pp. 202-213.

120. Forester, J.; Kuitenbrouwer, M.; Laws, D. Enacting reflective and deliberative practices in action research. Policy Stud. 2019, 40, 456-475. [CrossRef]

121. Bragaglia, F. Social innovation as a 'magic concept' for policy-makers and its implications for urban governance. Plan. Theory 2020, 1-19. [CrossRef]

122. Fielding, N.G. Triangulation and mixed methods designs: Data integration with new research technologies. J. Mix. Methods Res. 2012, 6, 124-136. [CrossRef]

123. Yin, R.K. Applications of Case Study Research; SAGE: London, UK, 2011.

124. Bauwens, M.; Vasilis, K. From the Communism of Capital to Capital for the Commons: Towards an Open Cooperativism. Triple C: Commun. Capital. Crit. 2014, 12, 356-361. [CrossRef]

125. Bauwens, M.; Kostakis, V.; Pazaitis, A. Peer to Peer: The Commons Manifesto; University of Westminster Press: London, UK, 2019.

126. Bauwens, M.; Pazaitis, A. P2P Accounting for Planetary Survival. P2P Foundation, Guerrilla Foundation and Schoepflin Foundation: Ghent, Belgium, 2018. 
127. Hardjono, T.; Pentland, A. Empowering artists, songwriters \& musicians in a data cooperative through blockchains and smart contracts. arXiv 2019, arXiv:1911.10433v1.

128. OECD. Social Economy and the COVID-19 Crisis: Current and Future Roles; OECD: Paris, France, 2020.

129. Novara Media. Reclaiming Work: The Cycle Couriers Subverting the Gig Economy. Available online: https://www.youtube.com/watch?v=I0Z5PBgwu60 (accessed on 1 August 2020).

130. ECFR (European Council on Foreign Relations). Europe's Digital Sovereignty: From Rulemaker to Superpower in the Age of US-China Rivalry; ECFR: Brussels, Belgium, 2020.

131. Floridi, L. The fight for digital sovereignty: What it is, and why it matters, especially for the EU. Philos. Technol. 2020, 33, 369-378. Available online: https://thephilosophyofinformation.blogspot.com/2020/08/the-fight-fordigital-sovereignty-what.html (accessed on 12 August 2020). [CrossRef]

132. Johar, I.; Begovic, M. A Way Forward: Governing in an Age of Emergence; Dark Matter Labs \& UNDP: London, UK, 2020.

(C) 2020 by the author. Licensee MDPI, Basel, Switzerland. This article is an open access article distributed under the terms and conditions of the Creative Commons Attribution (CC BY) license (http://creativecommons.org/licenses/by/4.0/). 